\title{
ON THE HEMOTOXIN OF THE SARCOSPORIDIA
}

\author{
Shrnich Sato, \\ Assistant in the Kitasato Institute for Infectious Diseases \\ (Frm the Medico-zoological Institute, Keio University. C'ief: \\ Dr. Makoto KoIzUMI)
}

(Received for publication October 16, 19:9)

In literature, the studies on the activators in connection with this toxin, in especial reference to hemolysis, such as lecithin or serum, as they have been used in hemolysis by snake venoms or other sorts of phyto-toxins, have been scarce. Only the papers accessible to me were those of Teichmann ${ }^{(1)}$ and Cominotti ${ }^{(3)}$, who tested the hemolytic action of sarcosporidiotoxin against the erythrocytes of the rabbit, sheep and horse. They all report a negative result. Teichmann and Braun ${ }^{(2)}$ later report that in this toxin they proved hemagglutinative principle.

As was reported in my preliminary communications ${ }^{(4)}$, I have proved on the hemagglutinative and hemolytic principles in the sarcosporidiotoxin, which consisted of the dessicated specimens of the Sarcocystis blanchardi found parasitic in the Formosan buffaloes. Concerning the facts that a very scrupulous care is necessary in preparing the infusum; that the results obtained by the use of the erythrocytes of various species of animals are divergent; that it has its attitude toward sera and their components, especially lecithin, cholesterol and serum proteins, and that it has specific physicochemical and serological natures, this toxin would seem widely different from other zootoxins. The results are dealt with in this paper.

\section{Physico-chemical Natures}

The hemolytic principle, which is found in the sarcosporidiotoxin is alcohol and ether soluble, but hardly soluble in either distilled water or physiological saline. It would seem very probable that 
it has something of a colloidal construction. It can hardly be demonstrated, if the technique of the preparation of the infusum, especially the maceration should be imperfect. The hemolytic principle of the toxin, again, is thermostabile but if the freshly prepared material should be heated at $65^{\circ} \mathrm{C}$. or above the principle in question will be brought down with the precipitates. This is another point of notice in the demonstration of the hemolytic activity of this toxin. In the following Table I, the prominent characteristics of the hemagglutinative and hemolytic principles are shown :

Table I

\begin{tabular}{|c|c|c|}
\hline Natures & Hemolytic principle & $\begin{array}{l}\text { Hemagglutinative } \\
\text { principle }\end{array}$ \\
\hline Solubility : in distilled water & Hardly soluble & Soluble \\
\hline "the saline & Hardly soluble & Soluble \\
\hline " glycerine water & $\begin{array}{l}\text { Hardly soluble (action is } \\
\text { interrupted by glycerine) }\end{array}$ & $\begin{array}{l}\text { Soluble (action is not in- } \\
\text { terrupted by glycerine) }\end{array}$ \\
\hline " alcohol-water & Soluble & Insoluble \\
\hline " ether-water & Soluble & Insoluble \\
\hline Resistances : against heat & Stabile up to $120^{\circ} \mathrm{C}, 2$ hours & $\begin{array}{l}\text { Destruyed by } 85^{\circ} \mathrm{C}, 1 / 2 \\
\text { hour }\end{array}$ \\
\hline$\prime \prime$ acid & $\begin{array}{l}\text { Comparatively strong again- } \\
\text { st acid, but weak against } \\
\text { alkalies }\end{array}$ & $\begin{array}{l}\text { Strong against acid but } \\
\text { very weak against alka- } \\
\text { lies }\end{array}$ \\
\hline Dialyzation: & Not dialyzable & Not dialyzable \\
\hline Adsorption : & $\begin{array}{l}\text { Adsorbed by animal char- } \\
\text { coal and caorin }\end{array}$ & $\begin{array}{l}\text { Adsorbed by animal char- } \\
\text { coal and caorin }\end{array}$ \\
\hline Protein reactions: & Negative & Positive \\
\hline
\end{tabular}

Action of the Hemotoxin Alone against the Washed Erythrocytes

Hemolytic and Hemagglutinative Actions: The sarcosporidiotoxin has divergent strengths of both hemolytic and hemagglutinative actions against the washed erythrocytes of animals, which are shown in the following Table II:

Table II

\begin{tabular}{|l|c|c|c|c|c|c|}
\hline $\begin{array}{l}\text { Sources of eryth- } \\
\text { rocytes (in a 5\% } \\
\text { suspension) }\end{array}$ & \multicolumn{2}{|c|}{ Toxin alone } & \multicolumn{2}{|c|}{ With 20\% serm } & \multicolumn{2}{|c|}{ With lecithin } \\
\cline { 2 - 7 } & Heml.* & Hemag ** & Heml. & Hemag. & Heml. & Hemag. \\
\hline Guinea-pig & $\begin{array}{l}\mathbf{3} 200- \\
6400\end{array}$ & 25600 & $\begin{array}{c}\frac{1}{1} \\
(200)\end{array}$ & $\begin{array}{c}51200 \\
\text { (raised) }\end{array}$ & $\begin{array}{c}51200 \\
\text { (raised) }\end{array}$ & $\begin{array}{l}\text { Uninfluenced } \\
\text { if not raised }\end{array}$ \\
\hline
\end{tabular}




\begin{tabular}{|c|c|c|c|c|c|c|}
\hline Horse & $\begin{array}{l}1600- \\
3200\end{array}$ & 51200 & - & $\begin{array}{l}102400 \\
\text { (raised) }\end{array}$ & $\begin{array}{r}25600 \\
\text { (raised) }\end{array}$ & $\begin{array}{l}\text { Somewhat } \\
\text { lowered }\end{array}$ \\
\hline Rabbit & $\begin{array}{l}800- \\
1600\end{array}$ & 102400 & - & Uninfluenced & $\begin{array}{r}640 \\
\text { (raised) }\end{array}$ & do. \\
\hline Goat & $\begin{array}{r}800- \\
1600\end{array}$ & 12800 & - & do. & $\begin{array}{r}12800 \\
\text { (raised) }\end{array}$ & Uninfluenced \\
\hline Pig & $\begin{array}{r}800 \\
1600\end{array}$ & 51200 & - & do. & $\begin{array}{r}6400 \\
\text { (raised) }\end{array}$ & do. \\
\hline Dog & $\begin{array}{l}400- \\
800\end{array}$ & 51200 & - & do. & $\begin{array}{r}6400 \\
\text { (raised }\end{array}$ & $\begin{array}{l}\text { Somewhat } \\
\text { lowered. }\end{array}$ \\
\hline Buffalo & $\begin{array}{l}400- \\
800\end{array}$ & 204800 & - & do. & $\begin{array}{r}3200 \\
\text { (raised) }\end{array}$ & $\begin{array}{l}\text { Uninfluenced } \\
\text { if not lowered }\end{array}$ \\
\hline Human & $\begin{array}{l}400- \\
800\end{array}$ & 102400 & - & do. & $\begin{array}{r}6400 \\
\text { (raised) }\end{array}$ & $\begin{array}{l}12800 \text { (mar- } \\
\text { kedly lowered }\end{array}$ \\
\hline Chicken & 400 & 51200 & - & $\begin{array}{c}320 \\
\text { (lowered) }\end{array}$ & $\begin{array}{r}1600 \\
\text { (raised) }\end{array}$ & $\begin{array}{c}12800 \\
\text { (lowered) }\end{array}$ \\
\hline Pigeon & $400 ?$ & 51200 & - & $\begin{array}{c}12800 \\
\text { (lowered) }\end{array}$ & $800 ?$ & $\begin{array}{c}3200 \\
\text { (lowered) }\end{array}$ \\
\hline Duck & $400 ?$ & 102400 & - & $\begin{array}{c}51200 \\
\text { (lowered) }\end{array}$ & $800 ?$ & $\begin{array}{c}12800 \\
\text { (lowered) }\end{array}$ \\
\hline Sheep & $400 ?$ & 12800 & - & $\begin{array}{l}102400 \\
\text { (raised) }\end{array}$ & $?$ & $\begin{array}{l}102400 \\
\text { (raised) }\end{array}$ \\
\hline Cattle & $400 ?$ & 25600 & - & $\begin{array}{r}51200 \\
\text { (raised) }\end{array}$ & ? & Uninfluenced \\
\hline Formosan zebu & $400 ?$ & 12800 & - & uninfluenced & $?$ & do. \\
\hline
\end{tabular}

*Heml. stand for hemolysis and **Hemag. for hemagglutination.

From the above table, it will be seen that the hemolytic action was strongest against the erythrocytes of the guinea-pig among the erythrocytes of the 14 species of animals $(1 / 6400)$, next against those of the horse, rabbit, bog, pig, human and goat (1/3200-1/1 $600)$ while weakest against those of the buffalo, chicken, pigeon, duck, sheep, cattle and Formosan zebu (1/400). The hemagglutinative action was strongest against the erythrocytes of the buffalo (1/200 000), those of the human, duck and rabbit (1/100 000) stood next in order of strength while those of the dog, pigeon, horse, guinea-pig, sheep, cattle and Formosan zebu (1/50000-1) $10000)$ were the weakest.

The Optimal Concentration of the Erythrocytes for Two Reactions : The optimal concentration of the erythrocytal suspension for both hemolytic and hemagglutinative reactions was $2.5-5.0 \%$. The weaker the concentration was, the wider was the range of the hyperinhibitory phenomena. Even, when all the erythrocytes should 
be laked, the freed hemoglobin would be sedimented and the proper tonus of the color were made obscure and accordingly the judgement of the results was difficult to be established.

Velocity of the Development of Both Reactions: The velocity of the development of the reactions was not simultaneous with both tests, because the hemagglutinative reaction developed by far the speedier than the hemolysis, or the former reaction was seen to develop in several minutes, and the complete phenomena took place in two hours, while hemolysis began to develop gradually in one half to one hour and the development of the complate phenomena took place in about 20 hours.

Fixation of Erythrocytes and the Stromata: The hemotoxin fixes both the erythrocytes and the stromata in vitro. The fixation developed quite indifferently with the species of the animals, i. e. the erythrocytes which were keen to the action of the hemotoxin absorbed just in a magnitude similar to the duller erylhrocytes.

\section{Influences of the Sera upon the Hemotoxin}

Influence of Sera upon Hemolytic Toxin: The action of the hemolytic toxin is not accelerated by sera, whether they were homologous or inactivated heterologous or in whatever percentages they were used. If, however, the sera should be used in a very high percentage, (viz. 0.25 c.c. of a $20 \%$ solution), the hemolytic action was interrupted. The threshold dosis to inhibit the hemolysis against one unit of the toxin, i. e. 0.5 c.c. of a $1 / 400$ dilution of the toxin, was 0.5 c.c. of a $1 / 20$ dilution of the sera.

Action of the Heated Sera upon Hemolysis: The sera which had been heated at $65^{\circ}-100^{\circ} \mathrm{C}$. for one half hour, even had the inhibitory action against hemolysis. It has also been observed that the sera heated at $65^{\circ}-80^{\circ} \mathrm{C}$. had weaker inhibitory action than the fresh one, but those heated at $100^{\circ} \mathrm{C}$. had almost as strong inhibitory action as the latter.

Action of Sera upon Hemagglutination: Allowing a very slight dissemination arising from the use of different methods of mixing or the different sorts of the sera, it has been generally observed that the hemagglutination was weakened by keeping the 
mixture of the erythrocytal suspension and the sera at $37^{\circ} \mathrm{C}$. for one half hour, but if the erythrocytes alone should be treated with the sera before the addition of the toxin, the hemagglutinative activity has been seen somewhat increased.

If the sera should be treated with 10-20 times their volume of pure alcohol, the extracts accelerated the hemolytic action, while the insoluble portion acted inhibitorily against both hemolysis and hemagglutination. By investigating the acceleratory and inhibitory substance by chemical view point, the following results could be learnt :

\begin{tabular}{|c|c|}
\hline Substance & Reaction \\
\hline 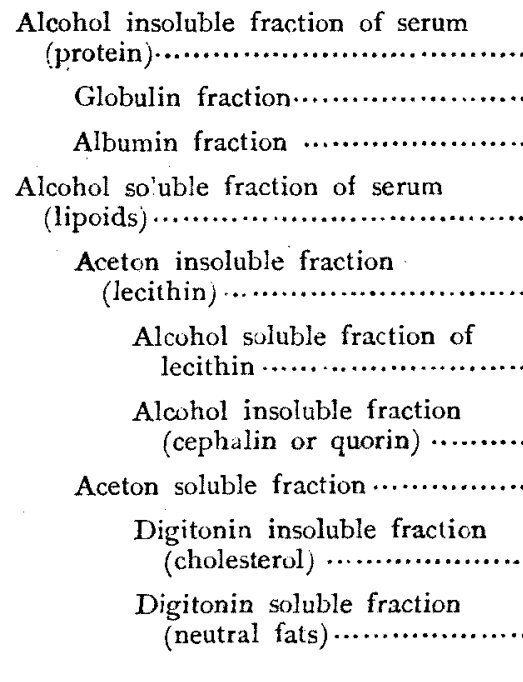 & $\begin{array}{l}\text { Inhibition of hemolysis very strong. } \\
\text { ditto weak; hemagglutination strong. } \\
\text { ditto strong : ditto weak. } \\
\text { Hemolysis } 4-8 \text { times as strong as when } \\
\text { toxin alone was used. } \\
\text { Hemolysis } 8 \text { times as strong as when } \\
\text { toxin alone was used. } \\
\text { Hemolysis } 16 \text { times as strong as when } \\
\text { toxin alone was used } \\
\text { Hemolysis indifferent. } \\
\text { Hemolysis } 2 \text { times as strong as when } \\
\text { toxin alone was used. } \\
\text { Enhibition of hemolysis: trace. } \\
\text { Hemolysis } 2 \text { times as strong as when } \\
\text { toxin alone was used. }\end{array}$ \\
\hline
\end{tabular}

From the above experimental data it was seen that:

(1) Amongst the alcohol soluble fraction in the serum, lecithin has the strongest power to accelerate the hemolysis by the sarcosporidiotoxin, while the neutral lipoids have a very strong power of autohemolysis, but very weak in accelerating the hemolytic power of the sarcosporidiotoxin. Cephalin and quorin are practically indifferent. It may be concluded, therefore, that hemolysis accelerating substance in the serum is lecithin fraction. Uf all the methods of mixing lecithin, the mixing of the toxin, erythrocytes and lecithin all at once gives the most vigorous action of hemolysis. This 
accelerating action of lecithin is strongest in the fresh preparation but the longer the preparation is preserved, the weaker its action was, while the stronger the autohemolytic power was.

(2) The cholesterol fraction has been found practically indifferent for inhibitory action against hemolysis. I have obtained a negative results in my test in which I employed the saline suspensoid of gelatin, as the protective colloid, and cholesterol, Merck, as the inhibitory agent against hemolysis.

(3) The albumin fraction, which is one of the alcohol insoluble serum proteins, is the chief substance to inhibit hemolysis. The threshold amount of complete inhibition against one unit of the hemolytic toxin was 0.25 c.c. of a $1 \%$ solution of the dried alconol insoluble substances of the serum, which when calculated to the corresponding amount of the original serum will be 0.5 c.c. of a $5 \%$ dilution.

Another alcohol insoluble fraction, globulin, has rather the action to inhibit the hemagglutination. This together with the hemolysis inhibitory principle of the albumin, is weakened by heating at $65^{\circ} \mathrm{C}$. or above.

\section{Mechanisms of the Combination of the Inhibitory Substances with the Toxin and Erythrocytes}

In order to determine what would be the mechanisms which play when the hemolysis inhibitory albumin fraction and the agglutination inhibitory globulin fraction would combine with toxin or erythrocytes, I have carried out the following experiments. The erythrocytes, the hemolysis and hemagglutination inhibitory substances and the toxin were mixed in vitro after various methods. The case in which the hemolysis inhibitory substance and the toxin had been first mixed and incubated at $37^{\circ} \mathrm{C}$. for one half hour and then the erythrocytes had been added, gave the strongest hemolysis inhibition but if the erythrocytes and the inhibitory substance had been mixed and then the toxin had been added or if the toxin and the erythrocytes had been mixed, the inhibition was weaker. The hemagglutination, however, developed quite indifferently if the mixture should be made after whatever method of mixing. These results would seem almost contradictory to what is obtained by the 
use of the serum instead of its components. They had a quite different physico-chemical nature from the original serum. They were hardly soluble in the saline and, therefore, if the solution of these substance should be left standing for a certain period of time or should it be centrifugalized, the inhibitory substances would be brought down and the supernatant fluid would contain only little of these substances. If, however, the precipitated fluid should be left standing for 24 hours or above, a large portion of the hemolysis inhibitory substance would again be dissolved into the saline. By making use of this nature, I carried out two sorts of absorption experiments and learnt some interesting facts.

(1) Combination Test of Toxin and the Inhibitory Substances : An equal amount of a $2 \%$ solution of the inhibitory substances, or alcohol insoluble fraction and a $1 / 200$ solution of the toxin, which had been proved to contain twice as much threshold amount of the hemolysis inhibitory substance against one unit of hemolytic toxin. The mixture was incubated at $37^{\circ} \mathrm{C}$. for $1 / 2-1$ hour. It was then centrifugalized to obtain the large portion of both the hemolysis inhibitory and the hemagglutination inhibitory substances. The actions of the supernatant fluid and the saline emulsion of the precipitates upon the erythrocytes and the hemotoxin had been tested and the following results were obtained:

Tabele III

\begin{tabular}{|c|c|c|c|}
\hline Preliminary treatment & Secondary treatment & Ifemolysis & Hemagglutination \\
\hline $\begin{array}{l}1 \text { unit of hemolysis plus } \\
\text { inhibitory substance } \\
\text { (heated at } 37^{\circ} \mathrm{C} \text {. for } 1 / 2 \\
\text { hour and then centrifu- } \\
\text { galized) }\end{array}$ & $\begin{array}{l}\text { Erythrocytes mixed } \\
\text { with the supernatant } \\
\text { fluid (heated at } 37^{\circ} \mathrm{C} \\
\text { for } 1 \text { hour) }\end{array}$ & Trace & Very strong \\
\hline ditto & do. and toxin & Very strong & Very strong \\
\hline ditto & $\begin{array}{l}\text { Erythrocytes mixed } \\
\text { with the precipitates }\end{array}$ & Trace & Trace \\
\hline ditto & ditto and toxin & Strong & Weak \\
\hline Control 1 & $\begin{array}{l}\text { Erythrocytes mixed } \\
\text { with toxin }\end{array}$ & Very strong & Very strong \\
\hline Control 2 & $\begin{array}{l}\text { Erythrocytes mixed } \\
\text { with inhibitory sus- } \\
\text { tance }\end{array}$ & Trace & Weak \\
\hline
\end{tabular}

There occurred very weak hemolysis but a very strong hemag- 
glutination when the supernatant fluid and the erythrocytes had been mixed. When the supernatant fluid, erythrocytes and toxin had been mixed, it gave very strong reactions to both hemolysis and hemagglutination. The mixture of both the erythrocytes and the precipitates gave a very weak if not practically a negative reaction to hemagglutination and hemolysis, while the mixture of the erythrocytes, precipitates and toxin gave a positive reaction to hemolysis and a very weak positive reaction to hemagglutination.

Judging from these experimental fact, it may be considered that the larger part of the hemolytic toxin would combine with the hemolysis inhibitory substance and is brought down into the precpitates, but hemagglutinin does not combine with the inhibitory substances. The large portion, however, would remain dissolved in the supernatant fluid. Moreover, the hemagglutination inhibitory substance would sediment by itself. It has been regretted that hemolysin could not be recovered from the sediments which consists of a combination of inhibitory substance and hemolysin.

(2) Combination of the Erythrocytes and Inhibitory Substance: The inhibitory substances which were employed in this experiment consisted of a $2 \%$ saline solution, which had been left standing for 24 hours from the dissolution. The solution was then mixed with the erythrocytes and left standing in the incubator at $37^{\circ} \mathrm{C}$. for one half hour, when it was centrifugalized. The erythrocytes here obtained was washed several times. The influences of the hemotoxin and of the supernatant fluid upon the treated erythrocytes were testę and the following results were obtained:

Table IV

\begin{tabular}{|c|c|c|c|}
\hline Experiment & Hemolysis & $\begin{array}{l}\text { Hemaggluti- } \\
\text { nation }\end{array}$ & Notices \\
\hline $\begin{array}{l}\text { One unit of hemolytic toxin } \\
\text { and guinea-pig erythrocytes } \\
\text { sensitized with inhibitory } \\
\text { substance }\end{array}$ & Strong & Weak & $\begin{array}{l}\text { Hemolysis inhibition: } \\
\text { weak } \\
\text { Hemagglutination in- } \\
\text { hibition: strong. }\end{array}$ \\
\hline $\begin{array}{l}\text { One unit of hemolytic toxin, } \\
\text { supernatant fluid and non-sen- } \\
\text { sitized guinea-pig erythrocy- } \\
\text { tes }\end{array}$ & Weak & Very strong & $\begin{array}{l}\text { Hemolysis inhibition: } \\
\text { strong } \\
\text { Hemagglutination in- } \\
\text { hibition : practically }\end{array}$ \\
\hline $\begin{array}{l}\text { Control 1: One unit of hemo- } \\
\text { lytic toxin and non-sensitized } \\
\text { guinea-pig erythrocytes }\end{array}$ & Very strong & Very strong & none \\
\hline $\begin{array}{l}\text { Control } 2 \text { : One unit of hemolytic } \\
\text { toxin, non-sensitized erythro- } \\
\text { cytes and inhibitory substance }\end{array}$ & Weak & Weak & \\
\hline
\end{tabular}


The sensitized erythrocytes produced a very weak hemagglutination, but a strong hemolysis. The inhibitory substances were found not absorbed by the erythrocytes but remained free in the supernatant fluid. This might be explained on the ground that the hemolysis inhibitory substances have a very weak affinity to the erythrocytes, but the hemagglutination inhibitory substance a very strong affinity.

From the above described experimental facts, it might be justified to conclude that the hemolysis inhibitory substances would act directly against the hemolytic toxin, while the hemagglutination inhibitory substance first act upon the erythrocytes-presumably the receptor, which has a strong affinity to hemagglutinin-and then inhibitorily against the hemagglutinin.

\section{Anti-body Formation}

By immunizing the rabbit with either fresh or formalin treated sarcosporidiotoxin, a specific antitoxin had been obtained. It produced positive results in complement fixation and precipitation tests. The antibody formation by the hemotoxin, however, has not been dealt with. I have prepared fresh, formalin treated and heated hemotoxin. They were either singly or after being mixed with the pig's serum as Sachs proposed in the production of immune bodies by alcoholic extracts of lipoids, forcibly injected into the rabbits. The results were as follows:

(1) The rabbit was immunized with fresh toxin by 14 injections and obtained the serum which neutralized 200 times as large as the lethal dosis. The serum gave a positive complement fixation test up to $1 / 160$ and precipitation test up to $1 / 250000$. This serm, however, gave almost the same results as the normal serum in hemolytic and hemagglutinative tests, without giving any evidence of specific antibody formation for both of these reactions.

The immunized serum, which had been treated with either formalin or heat, also gave the negative results as the fresh one.

(2) The Antibody Formation of the Mixture of the Alcoholic Extracts and the Pig Serum: The rabbit was injected intravenously with a dosis of 3.0 c.c. of a mixture of the alcoholic extracts and the pig serum. 10-14 injections were given in all and 
the serum was obtouined fiom the blood withdrawn a week after the last injection. The immune serum gave positive results to the complement fixation and precipitation test, but negative to antihernolytic and antihemagglutinative reactions.

Antitoxic Action of the Serum of the Rabbit Immunized with the Alcoholic Fatracts of the Toxin

It was interesting to note that although the immune serum with the mixture of the alcoholic extracts of the toxin and the pig serum, as well as the one prepared with the alcoholic extracts alone, gave a negative result in antihemagglutinative and antihemolytic reactions in vitro, but it neutralized the toxic principle in the animals, which were susceptible to the sarcosporidiotoxin. By further experiments, it was found that 0.0005 c.c. (several times as large as the lethal dosis) of the toxin could be completely neutralized by $0.05-0.5$ c.c. of the immune serum. From these experimental results, it would seem very probable that a certain portion of the sarcosporidiotoxin might be freed into alcohol in a state of so-called anatoxin, when it had been treated with a 90$95 \%$ alcohol.

\section{RÉSUMÉ and CONCLUSION}

1. Sarcosporidiotoxin contains hemolytic and hemagglutinative principles.

2. The optimal concentration of the erythrocytal suspension to test both of these reactions is $2.5-5.0 \%$.

3. The physico-chemical characteristics of these two principles of the toxin: Hemolytic principle is hardly soluble in water, saline and glycerinated saline, but the hemagglutinative principle is soluble in these media; the one is soluble in alcohol and ether, but the other insoluble; The one is thermostable, but the other is destroyed by heating at $85^{\circ} \mathrm{C}$. for $1 / 2$ hour; The one is negative to protein reaction test, but the other positive; Concerning their resistances against acid and alkali, dialysis and adsorption, both of them almost agreed with each other.

4. The normal serum acts indifferently up to a certain amount but above this limit, it rather inhibits hemolysis by the hemolytic 
principle of the Sarcosporidiotoxin.

5. Alcohol soluble fraction of the serum (or lecithin fraction) accelerates hemolysis by this toxin, but the insoluble fraction (or albumin fraction) and globulin fraction inhibit hemagglutinative action of the toxin.

6. It might be justifiable to conclude from the experimental data that the hemolysis inhibitory substance (albumin fraction) acts directly against hemolytic principle while the hemagglutination inhibitory substance (globulin fraction) first combines with the erythrocytes and consequently inhibits hemagglutination.

7. All the batches of the immune sera prepared with the sarcosporidiotoxin treated by divergent methods were indifferent to hemagglutination.

8. The serum of the rabbit immunized with the alcoholic extracts of the sarcosporidiotoxin, either simple or in mixture with the pig's serum, was indifferent in hemagglutination and hemolysis, but it neutralized the toxic principle.

\section{REFERENCES}

1. Teichmann, Ernst: Ueber das Gift der Sarcosporidien. Arch. f. Protistitenkunde,; XX. 97. 1910.

2. Teichmann, Ernst und F. Braun: Ueber ein Protozoentoxine. Arch. f. Protistenkunte, XXII. 351. 1911.

3. Cominotti, L: Ueber Sarcosporidien, Centralbl. f. Bakt. u. s. w., LXIX. 264. 1913.

4. Sato, Shinichi : On the Toxic Action of Sarcosporidiotoxin and its Serological Study (Japanese). Keioigaku, Vol. VI. No. 1, 1926. (Summarized in the Journal of the Japanese Society of Veterinary Science, Vol. V. No. 1, 1926].

\section{住肉胞子蟲血球毒二就テ \\ 住肉胞子蟲毒素研究其二}

佳 藤 新 一

(北 里 研究 所)

(昭和 4 年 10 月 16 日受附)

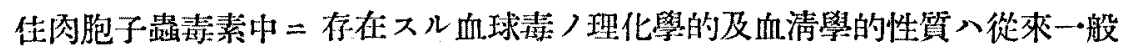


ニ知ラレタル動物性及植物性血球毒二對比シ大二趣 八浸出法二周到ナル注意 スル血清並ビ二血淸各成分就中れち」ん、てれすてりん及血清蛋白筫等ノ催

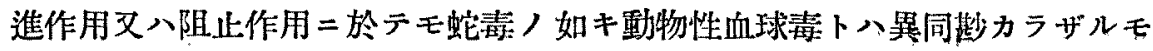
ノアリ次二其要點 7 抄錄スベシ

1. 住闪胞子蟲毒素中二ハ 2 種ノ血球毒郎チ溶血毒及血球凝集素存在シ恷 單獨 ニテ洗淮血球ニ對シテ溶血作用及血球凝集作用

2. 溶血作用 14 種ノ可檢血球中海㩧血球ガ最モ銳敏ニシテ(溶血價 6400 倍)馬、家鬼、犬、豚、人、山羊血球之二亞代 (3200-1600倍)水牛、䉆、沜、 家鴨、緬羊、牛及黃牛血球八弱度)溶血反應 7 呈

3. 血球凝集作用 水牛血球八最王高キ凝集價 鴨及家鬼血球八次＝位シ (100,000倍) 犬、鳩、馬、海猽、緬羊、牛、黄牛血 球卜順次凝集價低下ス（50000-10000倍）

4. 兩相血球表ノ反應 7 檢测 スルニハ $2.5-5 \%$ 血球浮游液適度ナリ血球 濃度之ョリ稀薄ナル時ハ過剩阻止現缘ノ圈域撜大シ且ツ血球八縱令溶血スル モ游離もくろびん沈潵シテ固有ノ色彩消失スルガ爲メ成樍〉鑑識困難ナリ

5. 血球毒ノ溶血作用及血球凝集作用八血球種類 相違アレドモ血球毒ト血球又八血球綱材トノ結合力（或八吸收力〉八血球種類 トハ無閵係ナリ

6. 兩種血球毒つ血球二對スル反應速度八相均シカラズ郎チ血球凝集素八 比較的迅速 =シテ血球二作用後數分間 =シテ現ハレ約 2 時間ニシテ頂點 =達 スルモ溶血毒ハ 30 分頃 $コ$ 徐そ二反應現ハレ約 20 時間ニシテ完成ス

7. 血球毒ノ理化學的性狀 兩種血球毒八溶解性及洏熱性二於テ著シキ相

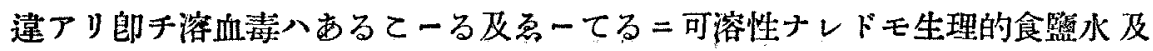
ぐりせりん食監水二八難溶性（恐ラクてろんど狀＝浮游シ來ルモノナルベシ）

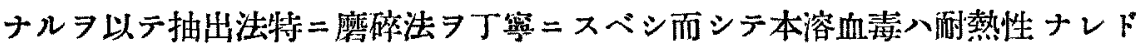

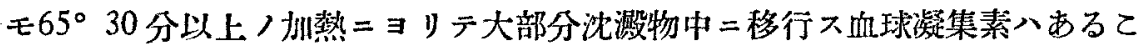
一る及㤩一てる $=$ 不溶性 $=シ テ$ 水及生理的食盅水等 $=$ 可溶性 $=シ テ 85^{\circ}: 0$ 分

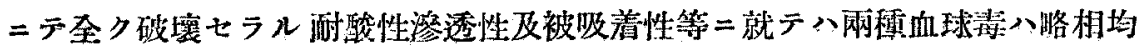




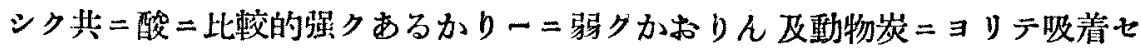
ラレ動物膜 ヨ通過セズ

8. 血球毒二及ス血清ノ作用 健康血清ハ少量ナレバ溶血湗二殆卜影響ナ キモ一定量以上 $\exists$ 混加スレバ溶血作用

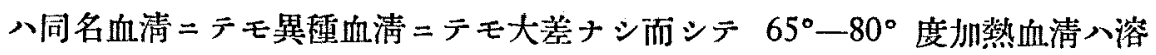
血阻止作用稍減弱スルモ $100^{\circ}$ 加等血球八却ツテ新鮮血球卜殆卜同程度ノ阻 止作用 7 呈 $ᄌ$

血球凝集素=對スル血清 $/$ 作用八混加八順序 $=ョ リ テ$ 多少相違シ前 $=$ 毒卜 血淸ト 作用シ後血球 加フル時八凝集價入一般二著明ノ減弱

9. 血清各成分/血球毒二對スル作用 血清ノあるこーる可溶成分八溶血 作用 $\exists$ 催進シ不溶成分八本血球婊 八溶血作用及血球凝集作用 7 阻害

（イ）溶血催進物質)主體八れち」ん・ふらくちよんニシテ中性脂肺八弱度

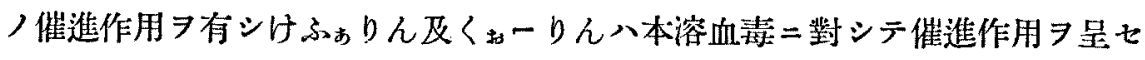
ズ

（口）てれすてりん八本溶血毒=對シテ殆卜何等ノ影響 7 呈セズ

（八）溶血阻止作用ノ主體八あるぶみん・ふらくちよんニシテぐろぶりん・ふ らくちょん八血球凝集阴止作用

10. 絬合又八吸收試驗 /結果ヨリシテ溶血阻止物質八直接=溶血表 $=$ 結合 シテ溶血阻止作用 7 呈シ血球凝集阻止物質入先ツ血球 $=$ 結合シ二次的二血球 凝集阻止作用习呈スルモノト考、ラル

11. 本血球毒ニ八抗元性

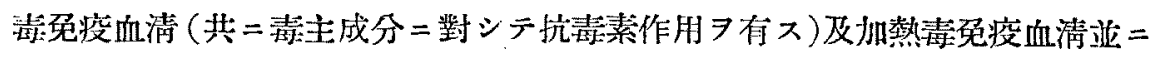

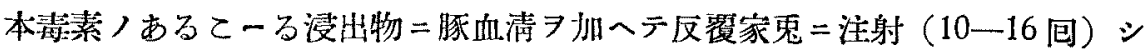
テ得タル免疫血清モ扰溶血體及抗血球凝集素习證明スルコト能ハズ 但シある こーる浸出毒㣻疾血清八豚血清 埥主成分二對シテ抗毒素作用 